\title{
Synthesis and characterization of SrO-containing bioglass-ceramic from rice husk silicon dioxide
}

\author{
(Síntese e caracterização de biovitrocerâmica com \\ adição de SrO a partir de sílica de casca de arroz)
}

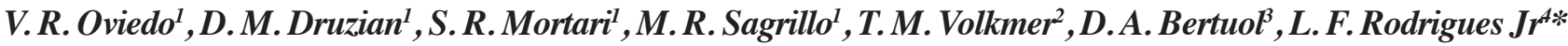 \\ ${ }^{I}$ Universidade Franciscana, Programa de Pós-Graduação em Nanociências, Santa Maria, RS, Brazil \\ ${ }^{2}$ Universidade Federal de Pelotas, Engenharia de Materiais, Pelotas, RS, Brazil \\ ${ }^{3}$ Universidade Federal de Santa Maria, Engenharia Química, Santa Maria, RS, Brazil \\ ${ }^{4}$ Universidade Franciscana, Engenharia Biomédica, R. Silva Jardim 1295, 97010-491, Santa Maria, RS, Brazil
}

\begin{abstract}
Rice husk is an abundant waste at the Rio Grande do Sul, Brazil, and it can be used to produce pure silicon dioxide, which is the main component of bioglass-ceramics. The addition of compounds, such as $\mathrm{SrO}$, can improve the biocompatibility of these biomaterials. Therefore, the goal of this paper was to use rice husk silicon dioxide as a cheap precursor to obtaining bioglass-ceramics of the system $50 \% \mathrm{SiO}_{2}-25 \% \mathrm{Na}_{2} \mathrm{O}-(25-\mathrm{x}) \% \mathrm{CaO}-\mathrm{x} \% \mathrm{SrO}(\mathrm{mol} \%)$ by sol-gel and investigate its potential use as a biomaterial. Two samples (BGC blank and BGC-5\% Sr) were synthesized and characterized by X-ray diffraction (XRD), Fourier-transform infrared spectroscopy (FTIR), and elemental carbon analysis by the combustion method. Scanning electron microscopy (SEM) was used to investigate the morphology of the bioglass-ceramics, while MTT assay of cell viability was used for in vitro characterization. The obtained silicon dioxide was amorphous and presented a small carbon content. Also, the bioglass-ceramics showed main phases with $\mathrm{Si}, \mathrm{Ca}, \mathrm{Na}$, and $\mathrm{Sr}$ on their structure. Both samples were not cytotoxic against peripheral blood mononuclear cells (PBMC), and the incorporation of $5 \% \mathrm{SrO}$ improved biocompatibility.
\end{abstract}

Keywords: biomaterials, bioceramics, rice husk, silica.

\section{Resumo}

A casca de arroz é um resíduo abundante no Rio Grande do Sul, Brasil, e pode ser utilizada para produção de sílica pura. As biovitrocerâmicas têm a sílica como principal componente. A biocompatibilidade desses materiais pode ser incrementada adicionando componentes, como $\mathrm{SrO}$. Este trabalho objetivou o uso da sílica proveniente da casca de arroz como um precursor de baixo custo para se obter biovitrocerâmica do sistema $50 \% \mathrm{SiO}_{2}-25 \% \mathrm{Na} \mathrm{O}_{-}-(25-x) \% \mathrm{CaO}-x \% \mathrm{SrO}(\%$ em mol) via sol-gel e investigar seu potencial como biomaterial. Duas amostras (BGC branco e BGC-5\%Sr) foram obtidas e caracterizadas por difração de raios $X$ (DRX), espectroscopia no infravermelho por transformada de Fourier (FTIR) e determinação de carbono elementar por método da combustão. A microscopia eletrônica de varredura (MEV) foi usada para investigar a morfologia das biovitrocerâmicas, enquanto o teste MTT de viabilidade celular foi usado para caracterização in vitro. A sílica obtida apresentou estrutura amorfa e pequena quantidade de carbono. As biovitrocerânicas apresentaram principalmente fases com Si, Ca, Na e Sr na sua estrutura. Ambas as amostras não apresentaram citotoxicidade frente às células mononucleares do sangue periférico (PBMC) e a incorporação de 5\% de $\mathrm{SrO}$ aumentou a biocompatibilidade.

Palavras-chave: biomateriais, biocerâmicas, casca de arroz, sílica.

\section{INTRODUCTION}

Rice is a cereal of great nutritional value found daily on worldwide meals. In Brazil, Rio Grande do Sul State is the greatest rice producer [1]. However, rice husk represents $20 \%$ of this amount, leading to the accumulation of residue [2]. Being mainly composed of silicon dioxide, lignin, and cellulose, rice husks can be used for producing silicabased materials as well as pure silicon dioxide [3]. When

*Dhttps://orcid.org/0000-0002-5753-5503 compared with other silicon dioxide sources such as sand, bentonite clay, and diatomite, it contains a small amount of contaminants that can directly affect the resulting material's performance on applications in which a high content of silicon dioxide is required [4]. The silicon dioxide can be obtained from rice husk by thermal treating, which can be enhanced by a previous acid/alkaline leaching process [5]. Due to the high content of silicon dioxide found on in natura rice husk [6], the resulting material has silicon dioxide content varying between $96 \%$ to $99 \%$ [7], strongly dependent on chosen processes, e.g., the parameters used in the leaching process (acid/base concentration, mixing time, 
use of surfactant) and thermal treatment (time, temperature, heating rate, atmosphere, etc.) [8].

Biomaterials have significantly contributed to improving the life quality of contemporary society [9]. Bioglasses and bioglass-ceramics are ceramic biomaterials that can promote biological responses from the material-tissue interface, and this allows the chemical bonds between tissue and implant to occur [10]. These biomaterials are known as bioactive because when they are implanted in the human body or in contact with body fluid, they promote the formation of a hydroxycarbonate-apatite (mineral found on bone tissue) surface layer. This phenomenon leads to the integration of the implant with the tissue, especially bone [11]. Two distinct routes can be used in the synthesis of those materials: the melt-quenching and the sol-gel methods. The meltquenching method uses high temperatures $\left(1100-1300{ }^{\circ} \mathrm{C}\right)$ and has the boiling of volatile compounds during the process as a disadvantage [12]. On the other hand, the sol-gel method uses low temperatures $\left(400-900{ }^{\circ} \mathrm{C}\right)$ and is characterized by process simplicity, high-purity, and homogeneity of resulting material [13]. In addition, it is worth pointing out that bioglasses and bioglass-ceramics obtained by the sol-gel method have higher biocompatibility and better structural properties than melt-quenching derived ones [14]. Due to their biocompatibility and osteoconductivity characteristics, bioglasses and bioglass-ceramics have been shown to be attractive materials for both tissue engineering and implant coating applications. In hard tissues, it is known that the strontium quantity is equal to $3.5 \%$ of calcium content [15], and that, in the human body, strontium is presented as a trace element in bone [16]. Therefore, it is assumed that the strontium incorporation into the bioglasses and bioglassceramics composition provides better biocompatibility [17].

Since rice husk is silicon dioxide-rich, the core component of bioglasses and bioglass-ceramics, its usage to produce these types of materials can lead to a reduction in environmental impacts related to this waste. Furthermore, it has great potential to produce high-quality and low-cost biomaterials, once the conventional methods need to use expensive silicon dioxide raw materials [18]. Thus, the current paper had as goals to use rice husk residue as raw material for silicon dioxide and obtain and characterize a strontium-containing bioglass-ceramic produced by the solgel method and its possible application as a biomaterial.

\section{MATERIALS AND METHODS}

Silicon dioxide extraction from rice husk: the rice husks were obtained from regional agroindustry (Camil Alimentos), originated from Itaqui, west border of Rio Grande do Sul State, Brazil; the soil of that region is a planosol [19], and the rice was grown in paddy fields under continuous flooding. The silicon dioxide extraction process was carried out through the following steps: milling and sifting; washing and chemical treatment; drying and thermal treatment. The milling and sifting steps were performed through a ball mill (CT-241, Servitech); a 30 min time was programmed, and stainless-steel sieves sizing 60 and 200 mesh were used, in this order. Then, the samples were weighed and divided into two parts: $\mathrm{CA}_{\text {in }}$ (in natura rice husk); and $\mathrm{CA}_{\mathrm{HCl}}$ (rice husk for chemical treatment with hydrochloric acid). After, the rice husks were washed with distilled water and left to dry at $60^{\circ} \mathrm{C}$ for $24 \mathrm{~h}$. The chemical treatment consisted of a leaching process. A solution of $0.5 \mathrm{~mol} . \mathrm{L}^{-1}$ hydrochloric acid (Química Moderna) was used to treat $\mathrm{CA}_{\mathrm{HCl}}$ sample. The procedure was carried out under reflux at $60{ }^{\circ} \mathrm{C}$ for $30 \mathrm{~min}$ [20], using a magnetic stirrer. The mass to volume ratio of rice husk and the acid solution was 50 g.L.- [21]. To eliminate acid residues, the sample was filtered and rinsed with distilled water at $70-80{ }^{\circ} \mathrm{C}$. After the chemical treatment, the sample was dried according to the same parameters described previously. The heat-treatment consisted of calcination performed in a furnace (MA358/3, Marconi) using the following parameters: $750{ }^{\circ} \mathrm{C}$ for $6 \mathrm{~h}$ and heating rate of $5^{\circ} \mathrm{C} \cdot \mathrm{min}^{-1}$ [22]. A slightly pink powder was obtained for the chemically untreated sample (named $\mathrm{CA}_{\mathrm{in}}-\mathrm{SiO}_{2}$ ) and a white powder for the chemically treated sample (named $\mathrm{CA}_{\mathrm{HCl}}-\mathrm{SiO}_{2}$ ). Based on the resulting elemental carbon content, the $\mathrm{CA}_{\mathrm{HCl}}-\mathrm{SiO}_{2}$ sample was used as raw material for the silicon dioxide.

Bioglass-ceramic synthesis: the sol-gel method was used to obtain the bioglass-ceramics and the reactants used were nitric acid (Synth) as a catalyzer, sodium hydroxide (Synth) as sodium precursor, tetrahydrate calcium nitrate (Synth) as calcium precursor, strontium nitrate (Alphatec) as strontium precursor, and $\mathrm{CA}_{\mathrm{HCl}}-\mathrm{SiO}_{2}$ sample as silicon dioxide precursor. Two compositions of bioglass-ceramics of the system $50 \% \mathrm{SiO}_{2}-25 \% \mathrm{Na}_{2} \mathrm{O}-(25-\mathrm{x}) \% \mathrm{CaO}-\mathrm{x} \% \mathrm{SrO}$ $(\mathrm{mol} \%)$ were studied, one without strontium addition (BGC blank) and another with strontium addition (BGC$5 \% \mathrm{Sr}$ ), as shown in Table I. The content of $5 \mathrm{~mol} \% \mathrm{SrO}$ was chosen based on other studies involving the substitution of $\mathrm{CaO}$ for $\mathrm{SrO}$ in bioglasses and bioglass-ceramics, which showed good in vitro results with human osteosarcoma cell lines (MG-63) [23], and good in vitro reactivity with this strontium content [24]. First, a sodium silicate $\left(\mathrm{Na}_{2} \mathrm{SiO}_{3}\right)$ solution was prepared in an open-system using a mixture of $50 \mathrm{~mL}$ of $1 \mathrm{~mol} . \mathrm{L}^{-1}$ sodium hydroxide $\left(\mathrm{Na}_{2} \mathrm{O}\right.$ precursor) and $2.5 \mathrm{~g}$ of silicon dioxide $\left(\mathrm{CA}_{\mathrm{HCl}}-\mathrm{SiO}_{2}\right)$ under the boiling condition at $100{ }^{\circ} \mathrm{C}$ during $1 \mathrm{~h}$. Afterward, the solution was vacuum filtered. Concomitantly, the calcium (4.92 g) and strontium $(0.365 \mathrm{~g})$ precursors were added to 15 $\mathrm{mL}$ of the concentrated nitric acid solution in this order at room temperature. To promote the proper hydrolysis and condensation of reactants, a $30 \mathrm{~min}$ time was respected between the additions of those precursors. After, the sodium silicate solution was added dropwise and under agitation to the other solution to form the sol. To complete the gelling process, the sol was left in rest overnight at room temperature. The obtained gel was aged in a stove at $70{ }^{\circ} \mathrm{C}$ for 3 days and, after that, it was dried at $150{ }^{\circ} \mathrm{C}$ for 2 days. Then, the resulting product was sintered in an oven at $700{ }^{\circ} \mathrm{C}$ for $2 \mathrm{~h}$ (heating rate of $5^{\circ} \mathrm{C} \cdot \mathrm{min}^{-1}$ ) to acquire dense form. The process flowchart is shown in Fig. 1. 


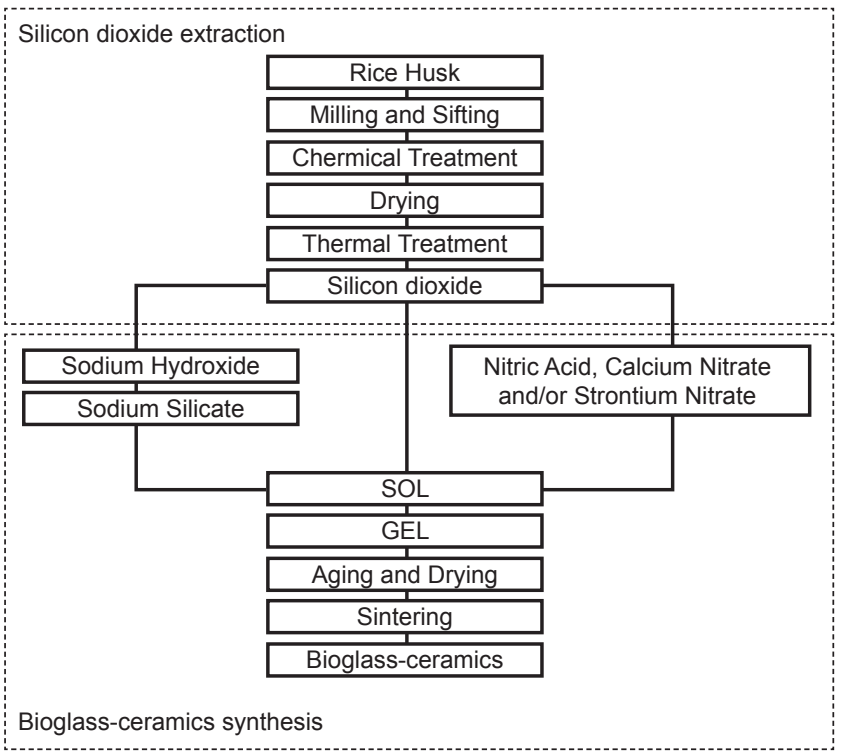

Figure 1: Flowchart of the bioglass-ceramic synthesis.

[Figura 1: Fluxograma da síntese das biovitrocerâmicas.]

Table I - Composition (mol\%) of bioglass-ceramics. [Tabela I - Composição (\% em mol) das biovitrocerâmicas.]

\begin{tabular}{ccccc}
\hline Sample & $\mathrm{SiO}_{2}$ & $\mathrm{Na}_{2} \mathrm{O}$ & $\mathrm{CaO}$ & $\mathrm{SrO}$ \\
\hline BGC blank & 50 & 25 & 25 & - \\
BGC-5\% Sr & 50 & 25 & 20 & 5 \\
\hline
\end{tabular}

Characterization. Structural characterization: in order to verify the present phases and their distributions on the final products, the X-ray diffraction (XRD) technique was used. The assay was performed using an X-ray diffractometer (D2 Phaser, Bruker) with a copper anode ( $\mathrm{CuK} \alpha$ radiation, $\lambda=1.5406 \AA$ ) and operated using the voltage and current values of $30 \mathrm{kV}$ e $10 \mathrm{~mA}$, respectively; $\mathrm{CA}_{\text {in }}$ (no calcinated), $\mathrm{CA}_{\mathrm{HCl}}$ (no calcinated), $\mathrm{CA}_{\mathrm{in}}-\mathrm{SiO}_{2}, \mathrm{CA}_{\mathrm{HCl}}-\mathrm{SiO}_{2}, \mathrm{BGC}$ blank, and $\mathrm{BGC}-5 \% \mathrm{Sr}$ samples were placed in standard sample holders, in powder form. The elemental carbon (C) content of the $\mathrm{CA}_{\mathrm{in}}-\mathrm{SiO}_{2}$ and $\mathrm{CA}_{\mathrm{HCl}}-\mathrm{SiO}_{2}$ samples was measured by the combustion analysis technique. On this assay, $50 \mathrm{mg}$ of samples were weighted and placed into tin capsules in an analyzer (FlashEA-1112, Thermo Fisher Sci.). This analysis was also used to select the best silicon dioxide precursor in bioglass-ceramic synthesis. Fourier-transform infrared spectroscopy (FTIR) was used to evaluate the functional groups presented in the BGC blank and BGC-5\% Sr samples. To perform FTIR analysis, the samples were mixed with $\mathrm{KBr}$ and prepared using a standard sample holder and a hydraulic press to form a pellet that was analyzed in a spectrometer (Spectro One, Perkin-Elmer). Morphological characterization: the scanning electron microscopy (SEM) was used to characterize sample morphology. The evaluation was performed using a scanning electron microscope (VEGA 3-SBU, Tescan Anal.) coupled with energy dispersive spectroscopy (EDS, INCA x-act, Oxford Instr.).

In vitro characterization: the MTT assay of cell viability was used to evaluate the cytotoxicity of the synthesized bioglass-ceramics. For this purpose, pellets of area and mass equal to $113.09 \mathrm{~mm}^{2}$ and $0.300 \mathrm{~g}$, respectively, were produced. The followed protocol was the same proposed in [25], and the procedure was performed in triplicate for BGC blank and BGC-5\%Sr samples, both in the pellet form and placed in a 12 well plate. The culture medium containing only peripheral blood mononuclear cells (PBMC) was used as a negative control $(\mathrm{CN})$. The PBMC separation step was done through a density gradient (Histopaque-1077) and centrifugation. The $2 \times 10^{5}$ cells. $\mathrm{mL}^{-1}$ concentration was achieved by counting the cells in a Neubauer chamber with $0.4 \%$ of trypan blue. After seeding, both cells and bioglassceramic samples were incubated in a $5 \% \mathrm{CO}_{2}$ environment at $37^{\circ} \mathrm{C}$ for $24 \mathrm{~h}$. The PBMC were obtained from peripheral blood samples discarded from LEAC (Clinical Analysis Lab. of the Franciscan Univ.) under the approval of the Ethics Committee on Human Research of the Franciscan Univ., CAAE $n^{\circ}$ 31211214.4.0000.5306, with no identification data. The results were obtained as a function of optical density. They were calculated through spectrophotometry at the $570 \mathrm{~nm}$ wavelength, and Eq. A. For this assay, statistical analyses with a $95 \%$ confidence interval were also used. The chosen methods were the one-way ANOVA followed by Dunnett's post hoc test for the mean comparing between the samples and the negative control.

$$
\text { Cell viability }(\%)=\frac{\mathrm{OD}_{570 \mathrm{e}}}{\mathrm{OD}_{570 \mathrm{~b}}} .100
$$

where: $\mathrm{OD}_{570 e}$ : mean value of the measured optical density of $100 \%$ of the extract of the test sample; and $\mathrm{OD}_{570 b}$ : mean value of the measured optical density of the blanks.

\section{RESULTS AND DISCUSSION}

The silicon dioxide production yield was $20 \%$ calculated by:

$$
\mathrm{SiO}_{2} \text { production yield }=\frac{\mathrm{m}_{\mathrm{RH}}-\mathrm{m}_{\mathrm{SiO}_{2}}}{\mathrm{~m}_{\mathrm{RH}}} .100
$$

where: $\mathrm{m}_{\mathrm{RH}}$ : initial mass of rice husk; and $\mathrm{m}_{\mathrm{SiO} 2}$ : final mass of silicon dioxide obtained from rice husk. Thus, following the present methodology, $100 \mathrm{~g}$ of in natura rice husks generate around $20 \mathrm{~g}$ of resulting material, which is associated with a high content of silicon dioxide $[4,6,20]$. Despite its low market value, it is acceptable due to the rice husk be an abundant waste in the South Region of Brazil [26].

Fig. 2 shows the XRD results for the $\mathrm{CA}_{\mathrm{in}}, \mathrm{CA}_{\mathrm{HCl}}, \mathrm{CA}_{\mathrm{in}}-$ $\mathrm{SiO}_{2}$, and $\mathrm{CA}_{\mathrm{HCl}}-\mathrm{SiO}_{2}$ (silicon dioxide precursor) samples. In the $\mathrm{CA}_{\text {in }}$ and $\mathrm{CA}_{\mathrm{HCl}}$ samples, the correspondent regions of $16^{\circ}, 22^{\circ}$, and $35^{\circ}$ were associated with the I-cellulose [27]. It is worth pointing out that the complete thermal decomposition of these materials is assured at temperatures above $360{ }^{\circ} \mathrm{C}$ [28]. Despite the great similarity of $\mathrm{CA}_{-}-\mathrm{SiO}_{2}$ and $\mathrm{CA}_{\mathrm{HCl}}-\mathrm{SiO}_{2}$ diffractograms, it was assumed that there was a difference in respect of the silicon dioxide content of these two samples, which was confirmed by the results of elemental carbon analysis. The found XRD patterns of silicon 
dioxide presented an amorphous nature [29] and were like those found in the literature $[4,18,20,28]$. The calcination temperature was adequate to avoid the crystallization of silicon dioxide obtained from the rice husk, and the chemical treatment was important to solubilize and remove alkali metals, alkaline-earth metals, and other metallic elements present in the husk [30]. It is reported in the literature [4, $18,20,28,31]$ that the silicon dioxide content of samples obtained from similar methodologies was between 95 to 99 $\mathrm{wt} \%$ of $\mathrm{SiO}_{2}$. Besides that, the elemental carbon content was used to compare $\mathrm{CA}_{\mathrm{in}}-\mathrm{SiO}_{2}$ and $\mathrm{CA}_{\mathrm{HCl}}-\mathrm{SiO}_{2}$ samples with respect to their purity. As aforementioned, the elemental carbon content had a crucial role in selecting $\mathrm{CA}_{\mathrm{HCl}}-\mathrm{SiO}_{2}$ as the raw material for silicon dioxide in bioglass-ceramic synthesis.

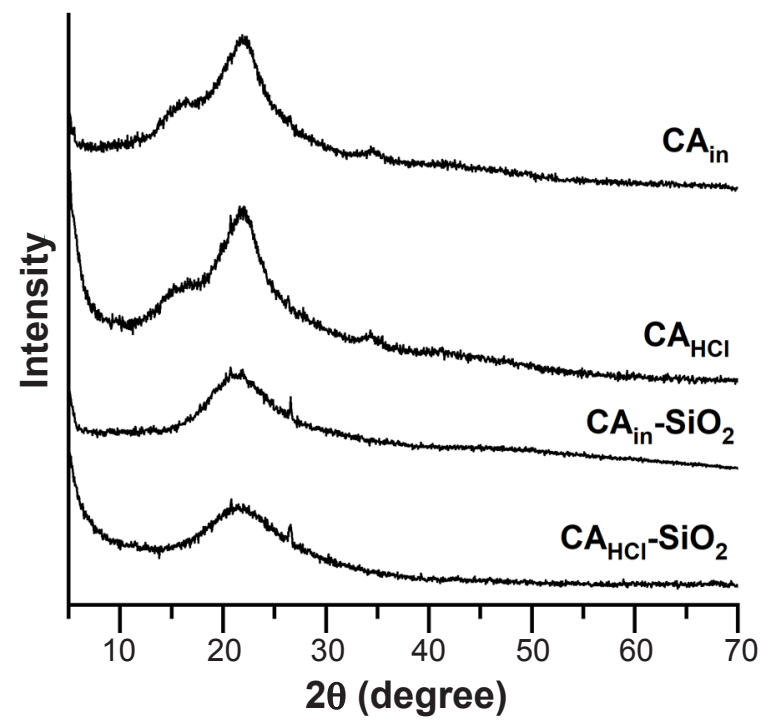

Figure 2: XRD patters for $\mathrm{CA}_{\mathrm{in}}, \mathrm{CA}_{\mathrm{HCl}}, \mathrm{CA}_{\mathrm{in}}-\mathrm{SiO}_{2}$, and $\mathrm{CA}_{\mathrm{HCl}}-\mathrm{SiO}_{2}$ samples.

[Figura 2: Difratograma de raios $X$ para as amostras $C A_{i n}, C A_{H C l}$, $\mathrm{CA}_{i n}-\mathrm{SiO}_{2}$ e $\mathrm{CA}_{\mathrm{HCl}}-\mathrm{SiO}_{2}$.]

Table II shows the elemental carbon content present in the $\mathrm{CA}_{\mathrm{in}}-\mathrm{SiO}_{2}$ and $\mathrm{CA}_{\mathrm{HCl}}-\mathrm{SiO}_{2}$ samples. It was noted that the used procedure for silicon dioxide extraction decreased the elemental carbon content during the thermal treating. This led to even lower values than reported in the literature [32], and highlighted the absence of carbon in the $\mathrm{CA}_{\mathrm{HCl}^{-}}$ $\mathrm{SiO}_{2}$ sample. This finding showed the efficacy of chemical treatment on contaminant removal.

Concerning the bioglass-ceramics, Fig. 3 shows the XRD results before and after the sintering process. As seen in Fig. 3a, there was the formation of sodium nitrate $\left(\mathrm{NaNO}_{3}\right.$,

Table II - Elemental carbon content in the samples. [Tabela II - Teor de carbono elementar nas amostras.]

\begin{tabular}{ccc}
\hline Sample & $\mathrm{n}$ & $\operatorname{Carbon}^{\mathrm{a}}(\%)$ \\
\hline $\mathrm{CA}_{\mathrm{in}}-\mathrm{SiO}_{2}$ & 2 & $0.106 \pm 0.018$ \\
$\mathrm{CA}_{\mathrm{HCl}}-\mathrm{SiO}_{2}$ & 2 & $0 \pm 0$ \\
\hline
\end{tabular}

${ }^{a}$ mean \pm standard deviation.
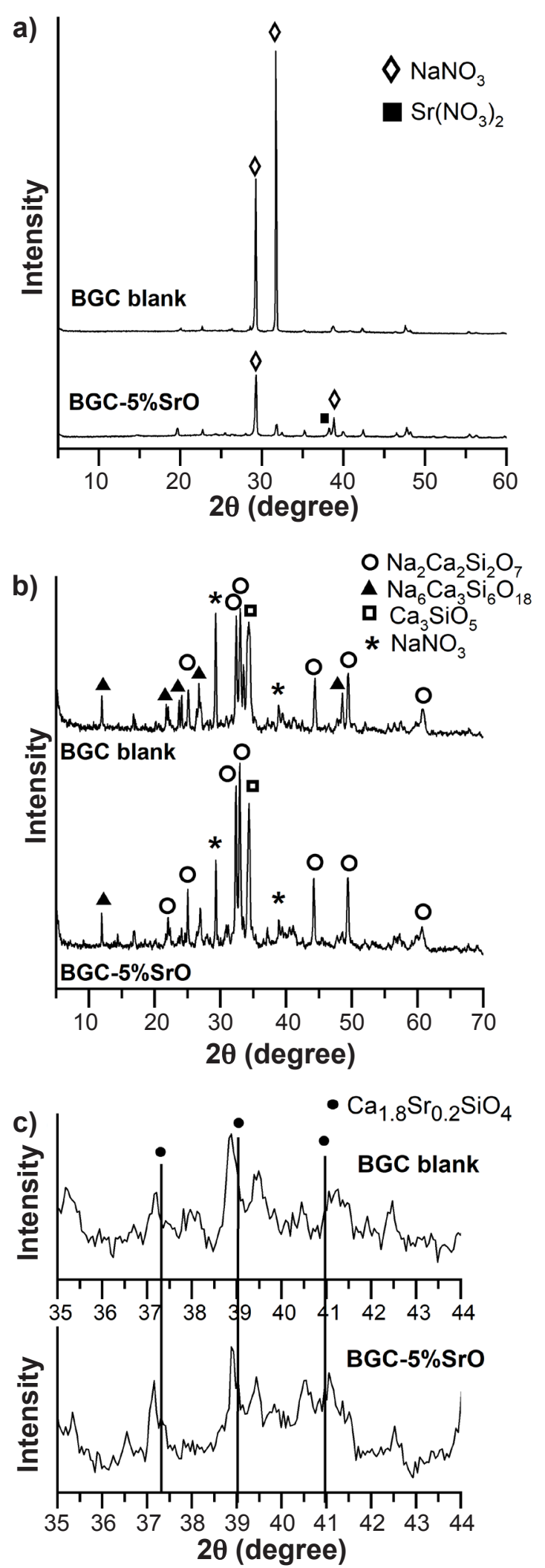

Figure 3. XRD patterns for BGC blank and BGC-5\%Sr samples: a) before sintering; b) after sintering at $700{ }^{\circ} \mathrm{C}$ for $2 \mathrm{~h}$; and c) enlarged patterns in the range of $35^{\circ}$ to $44^{\circ}(2 \theta)$ of sintered samples.

[Figura 3. Difratogramas de raios $X$ para amostras $B G C$ branco e BGC-5\%Sr: a) antes da sinterização; b) após sinterização a $700{ }^{\circ} \mathrm{C}$ por $2 \mathrm{~h}$; e c) difratogramas ampliados na faixa de $35^{\circ}$ a $44^{\circ}(2 \theta)$ das amostras sinterizadas.] 
ICDD 00-036-1474) and strontium nitrate $\left[\mathrm{Sr}\left(\mathrm{NO}_{3}\right)_{2}\right.$, ICDD $00-$ 025-0746] crystalline phases during the synthesis, which were associated to sodium and strontium nitrate precursors. Fig. 3b shows the XRD results for the same samples (BGC blank and

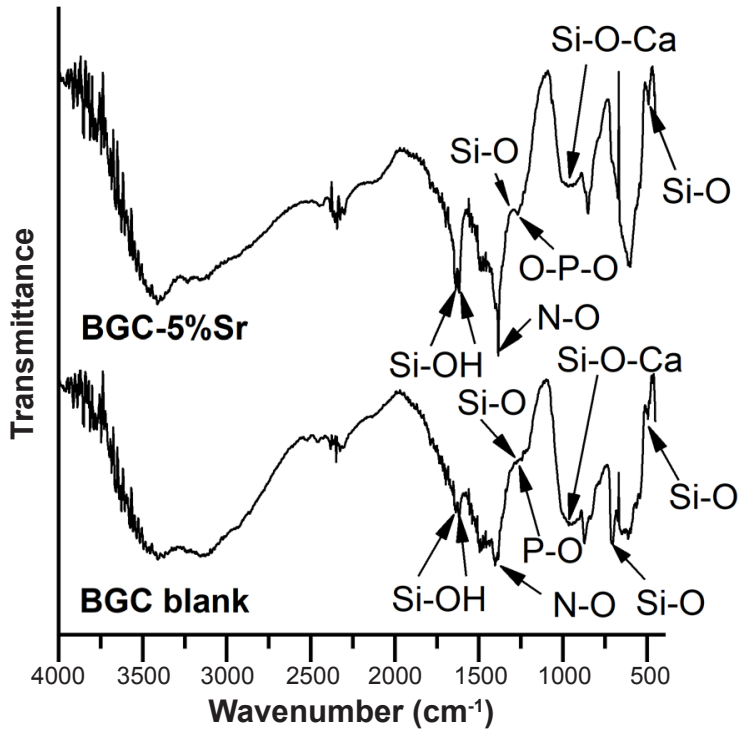

Figure 4: FTIR spectra for BGC blank and BGC-5\%Sr samples. [Figura 4: Espectros de FTIR das amostras BGC branco e BGC$5 \%$ Sr.]
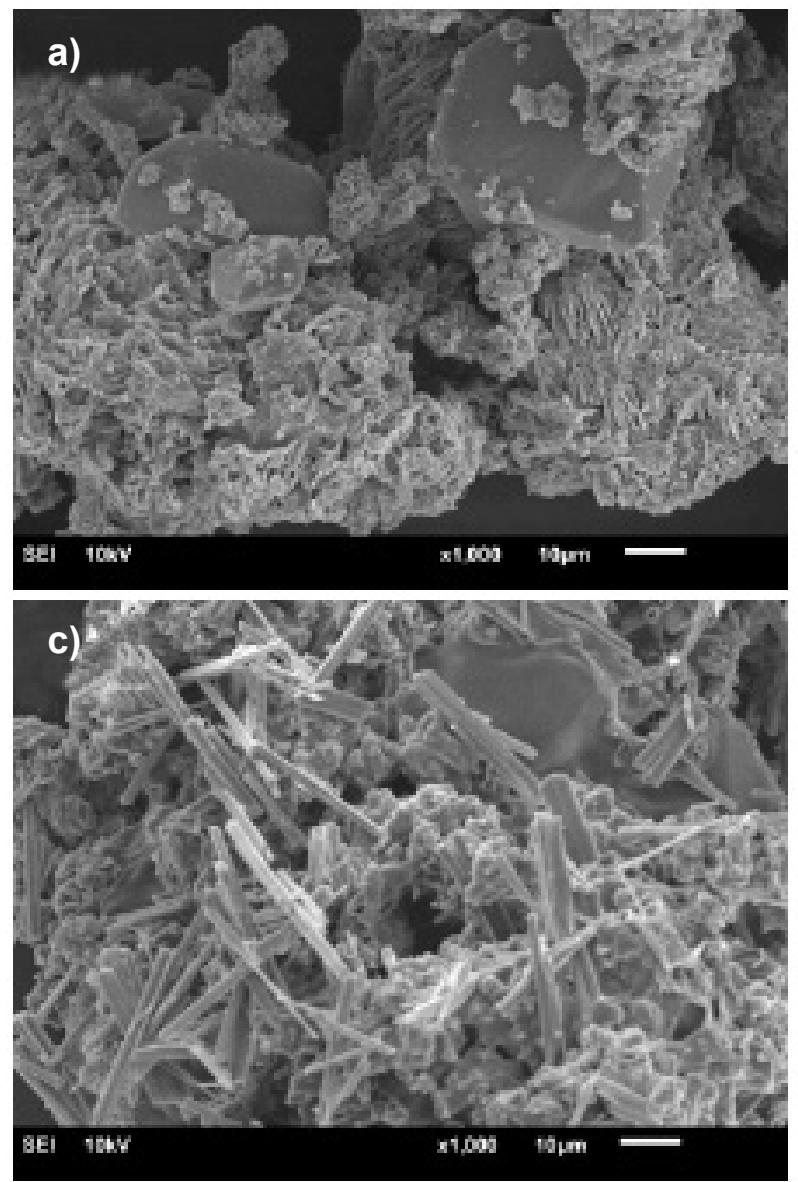

BGC-5\%Sr) after the sintering process. In BGC blank, there were characteristic peaks of $\mathrm{Na}_{2} \mathrm{Ca}_{2} \mathrm{Si}_{2} \mathrm{O}_{7}$ (ICDD 01-072-6024) $[33,34], \mathrm{Na}_{6} \mathrm{Ca}_{3} \mathrm{Si}_{6} \mathrm{O}_{18}$ (combeite-type, ICDD 01-077-2189) [34-36], and $\mathrm{Ca}_{3} \mathrm{SiO}_{5}$ (tricalcium silicate, ICDD 00-017-0445) [37]. In an analogous way, there was also the occurrence of these crystalline peaks in $\mathrm{BGC}-5 \% \mathrm{Sr}$ after the sintering process. It is known that the type of crystalline phases directly affects the biocompatibility and apatite formation [38, 39]. Also, tricalcium silicate phase may be beneficial to the structure, since $\mathrm{Ca}_{3} \mathrm{SiO}_{5}$ is also known as a biocompatible material [40]. The formation of $\mathrm{Na}_{2} \mathrm{Ca}_{2} \mathrm{Si}_{2} \mathrm{O}_{7}$ and $\mathrm{Na}_{6} \mathrm{Ca}_{3} \mathrm{Si}_{6} \mathrm{O}_{18}$ in a semi-crystalline structure also showed a typical bioglass-ceramic nature for both samples (BGC blank and BGC-5\%Sr) [23], and this can provide better mechanical properties [41], lesser susceptibility to contamination, and greater durability $[42,43]$, compared to the conventional bioglasses (completely amorphous structure). Moreover, when the two diffractograms were amplified and compared in the same chart (Fig. 3c), it was possible to find a calcium strontium silicate phase in the form of $\mathrm{Ca}_{1.8} \mathrm{Sr}_{0.2} \mathrm{SiO}_{4}$ (ICDD 01-077-1621) at the regions of $37.5^{\circ}, 39^{\circ}$, and $41^{\circ}$, which was only present in the $\mathrm{BGC}-5 \% \mathrm{Sr}$ sample; the presence of this phase indicated the incorporation of strontium in the $\mathrm{BGC}-5 \% \mathrm{Sr}$ sample's structure; the same result was also found in [44].

Fig. 4 shows that the FTIR spectra for the two samples were very similar, with just a few differences, indicating that
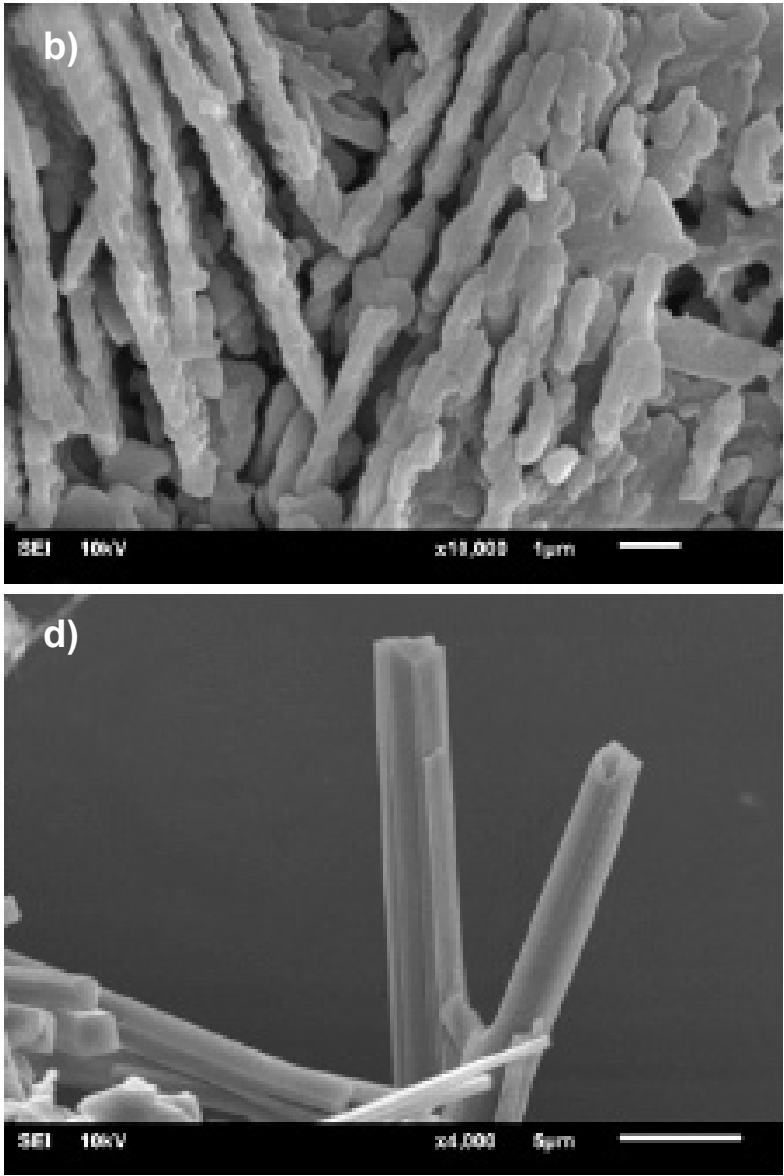

Figure 5: SEM micrographs for BGC blank (a,b), and BGC-5\% Sr (c,d) samples with different magnifications. [Figura 5: Micrografias de MEV para amostras BGC branco $(a, b)$ e BGC-5\%Sr $(c, d)$ em diferentes aumentos.] 
the incorporation of strontium on the bioglass-ceramics did not promote great modifications to material structure. The peaks at $494 \mathrm{~cm}^{-1}$ for BGC blank and $490 \mathrm{~cm}^{-1}$ for BGC-5\%Sr were related to $\mathrm{Si}-\mathrm{O}$ bond, as well as the shoulder at 1290 and 1262 $\mathrm{cm}^{-1}$ was associated with bending of the same bond [45]. Also, according to [45], there were Si-O-Ca bonds represented by 980 and $976 \mathrm{~cm}^{-1}$ bands for BGC blank and BGC-5\% Sr, respectively, and $\mathrm{Si}-\mathrm{OH}$ groups were also observed by the peaks at 1642 and $1636 \mathrm{~cm}^{-1}$ for BGC blank and BGC-5\% Sr, respectively. The same silanol groups could be formed by bonding with hydrogen atoms of molecular water [46]. The main difference between BGC blank and BGC-5\%Sr was the $710 \mathrm{~cm}^{-1}$ peak that appeared only in the BGC blank, corresponding to a symmetric $\mathrm{Si}-\mathrm{O}-\mathrm{Si}$ bond of a crystallized silicate phase [47]. Additional P-O bonds were also showed in the BGC blank and BGC-5\%Sr samples. The 1240 and $1265 \mathrm{~cm}^{-1}$ bands suggested the presence of nonbridging $\mathrm{PO}_{2}$ bond in both samples [48, 49], as rice husk has some small amount of phosphorous even after thermal treating [50]. The peak at $1385 \mathrm{~cm}^{-1}$ for the two samples confirmed the presence of an $\mathrm{N}-\mathrm{O}$ bond [51] associated with $\mathrm{NaNO}_{3}$ groups, described earlier in XRD results. Furthermore, the FTIR results were in accordance with the XRD results.

Fig. 5 show the results of SEM. In Fig. 5a, the BGC blank sample presented agglomerates; at higher magnification (Fig. $5 b$ ), there were slightly elongated and non-directional structures. With respect to Figs. $5 \mathrm{c}$ and $5 \mathrm{~d}$, these elongated structures seemed to be more particular for BGC-5\% Sr than BGC blank sample. However, the elongated structures in BGC-5\% Sr appeared to have a more random characteristic; one possible explanation is that the addition of doping elements, such as strontium, tends to form longer crystals in the bioglass-ceramic matrix, in a way similar to reported in [52] for the synthesis of $\mathrm{Si}_{3} \mathrm{~N}_{4}$-bioglass composites.

Fig. 6 shows the results for the MTT assay of cell viability. The cellular viability of BGC blank was $92.3 \% \pm 2.1 \%(\mathrm{p}<0.05)$, while for BGC-5\% Sr was $100.7 \% \pm 0.6 \%(\mathrm{p}=0.01)$, not showing the significant difference from the negative control. Based on ISO 10993-5 [53], samples that present cellular viability greater

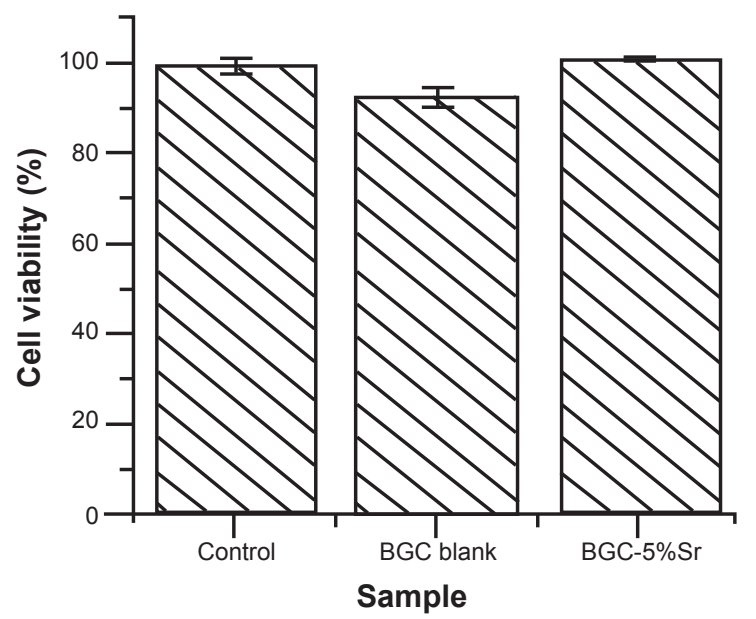

Figure 6: Results of MTT assay of cell viability after $24 \mathrm{~h}$ incubation.

[Figura 6: Resultados do teste de MTT de viabilidade celular após 24 de incubação.] than $70 \%$ are non-cytotoxic. Therefore, it was noticed that both samples did not present cytotoxicity against peripheral blood mononuclear cells, and the composition with $5 \mathrm{~mol} \%$ of $\mathrm{SrO}$ resulted in better biocompatibility characteristics $(\mathrm{p}<0.05)$, as expected. This can be explained by the fact that proper ion incorporation in biomaterials' structure, such as $\mathrm{Sr}^{2+}$, not only contributes to improved biocompatibility but also to bactericide properties [54]. Moreover, the MTT assay results indicated the potential success for future applications involving biomaterials and tissue engineering [55].

\section{CONCLUSIONS}

Bioglass-ceramics of the system $50 \% \mathrm{SiO}_{2}-25 \% \mathrm{Na}_{2} \mathrm{O}-(25-$ $\mathrm{x}) \% \mathrm{CaO}-\mathrm{x} \% \mathrm{SrO}$ were synthesized through the sol-gel method and using the silicon dioxide obtained from rice husk. The silicon dioxide presented an amorphous nature and was obtained by using chemical treatment with hydrochloric acid followed by calcination at $750{ }^{\circ} \mathrm{C}$ for $6 \mathrm{~h}$. The BGC blank $\left(50 \% \mathrm{SiO}_{2}-\right.$ $\left.25 \% \mathrm{Na}_{2} \mathrm{O}-25 \% \mathrm{CaO}\right)$ and BGC-5\% $\mathrm{Sr}\left(50 \% \mathrm{SiO}_{2}-25 \% \mathrm{Na}_{2} \mathrm{O}-\right.$ $20 \% \mathrm{CaO}-5 \% \mathrm{SrO}$ ) were tested in respect of their structure, morphology, and cytotoxicity. It was concluded that both samples were biocompatible, and the strontium incorporation led to better results related to the cytotoxicity against peripheral blood mononuclear cells.

\section{ACKNOWLEDGMENTS}

The authors would like to dedicate the acknowledgments to the Franciscan University for the opportunity to carry out this research, as well as for the available resources and infrastructure offered to us. The acknowledgments are also dedicated to CAMIL Alimentos S.A. for providing us the rice husks. This study was financed in part by the Coordenação de Aperfeiçoamento de Pessoal de Nível Superior - Brasil (CAPES) - Finance Code 001.

\section{REFERENCES}

[1] Comp. Nac. Abastec., "Acompanhamento da safra brasileira de grãos”, v.1, n.1, Conab, Brasília (2013).

[2] S. Azat, A. Korobeinyk, K. Moustakas, V. Inglezakis, J. Clean. Prod. 217 (2019) 352.

[3] M. Ali, M.A. Tindyala, J. Asian Ceram. Soc. 3, 3 (2015) 311. [4] I.J. Fernandes, D. Calheiro, F.A.L. Sánchez, A.L.D. Camacho, T.L.A.C. Rocha, C.A.M. Moraes, V.C. de Souza, Mater. Res. 20, 2 (2017) 512.

[5] J. Prasara-A, S.H. Gheewala, J. Clean. Prod. 167 (2018) 1020 .

[6] G.C. Ribeiro, B.A. Fortes, L. da Silva, J.A. Castro, S. Ribeiro, Cerâmica 65, Suppl.1 (2019) 70.

[7] L. Muniandy, F. Adam, A.R. Mohamed, E.-P. Ng, Micropor. Mesopor. Mater. 197 (2014) 316.

[8] Y. Shen, Renew. Sust. Energ. Rev. 80 (2017) 453.

[9] B.D. Ratner, A.S. Hoffman, F.J. Schoen, J.E. Lemons (Eds.), "Biomaterials science: an introduction to materials in medicine", $3^{\text {rd }}$ ed., Acad. Press (2013).

[10] L.L. Hench, N. Roki, M.B. Fenn, J. Mol. Struct. 1073 
(2014) 24.

[11] W. Leenakul, T. Tunkasiri, N. Tongsiri, K. Pengpat, J. Ruangsuriya, Mater. Sci. Eng. C 61 (2016) 695.

[12] K. Zheng, A. Solodovnyk, W. Li, O.-M. Gouduouri, C. Stähli, S.N. Nazhat, A.R. Boccaccini, J. Am. Ceram. Soc. 98, 1 (2015) 30.

[13] C.B. Carter, M.G. Norton, Ceramic materials: science and engineering, Springer, New York (2013) 411.

[14] D.S. Brauer, D. Möncke, in "Bioactive glasses: fundamentals, technology and applications", A.R Boccaccini, D.S Brauer, L. Hupa (Eds.), Royal Soc. Chem. (2016) 61.

[15] J. Liu, S.C.F. Rawlinson, R.G. Hill, F. Fortune, Dent. Mater. 32, 3 (2016) 412.

[16] J. Prejac, V. Višnjević, A.A. Skalny, A.R. Grabeklis, N. Mimica, B. Momčilović, J. Trace Elem. Med. Biol. 42 (2017) 11.

[17] J.R. Jones, Acta Biomater. 23 (2015) S53.

[18] F. Naghizadeh, M.R.A. Kadir, A. Dosstmohammadi, F. Roozbahani, N. Iqbal, M.M. Taheri, S.V. Naveen, T. Kamarul, J. Non. Cryst. Solids 427 (2015) 54.

[19] H.G. dos Santos, P.K.T. Jacomine, L.H.C. dos Anjos, V.Á. de Oliveira, J.F. Lumbreras, M.R. Coelho, J.A. de Almeida, J.C. de Araújo Filho, J.B. de Oliveira, T.J.F. Cunha, "Sistema brasileiro de classificação de solos", Embrapa, Brasília (2018).

[20] R.A. Bakar, R. Yahya, S.N. Gan, Procedia Chem. 19 (2016) 189

[21] N. Yalçin, V. Sevinç, Ceram. Int. 27, 2 (2001) 219.

[22] ASTM D3172-13, "Standard practice for proximate analysis of coal and coke", ASTM Int., USA (2013).

[23] M. Dziadek, B. Zagrajczuk, E. Menaszek, A. Wegrzynowicz, J. Pawlik, K. Cholewa-Kowalska, Ceram. Int. 42, 5 (2016) 5842.

[24] S. Solgi, M. Khakbiz, M. Shahrezaee, A. Zamanian, M. Tahriri, S. Keshtkari, M. Raz, K. Khoshroo, S. Moghadas, A. Rajabnejad, Silicon 9 (2017) 535.

[25] L.C. Wilms, P.C.H. Hollman, A.W. Boots, J.C.S. Kleinjans, Mutat. Res. Toxicol. Environ. Mutagen. 582, 1-2 (2005) 155 .

[26] E.O.B. Nara, J.A.R. Moraes, A.M.V. de Freitas, G. Rediske, G.B. Benitez, Cerâmica 60, 355 (2014) 340.

[27] N. Johar, I. Ahmad, A. Dufresne, Ind. Crops Prod. 37, 1 (2012) 93.

[28] J.A. Santana Costa, C.M. Paranhos, J. Clean. Prod. 192 (2018) 688 .

[29] N. Soltani, A. Bahrami, M.I. Pech-Canul, L.A. González, Chem. Eng. J. 264 (2015) 899.

[30] W. Xu, J. Wei, J. Chen, B. Zhang, P. Xu, J. Ren, Materials 11 (2018) 11.

[31] R.R. Menezes, E. Fagury-Neto, M.C. Fernandes, P.M. Souto, R.H.G.A. Kiminami, Cerâmica 54, 330 (2008) 245.

[32] M.A. Azmi, N.A.A. Ismail, M. Rizamarhaiza, W.M.
Hasif, A.A.K.H. Taib, AIP Conf. Proc. 1756 (2016) 20005. [33] F.M. Stábile, C. Volzone, J. Ortiga, Procedia Mater. Sci. 8 (2015) 332.

[34] J. Nayak, S. Kumar, J. Bera, J. Non-Cryst. Solids 356, 28-30 (2010) 1447.

[35] K. Fujikura, N. Karpukhina, T. Kasuga, D.S. Brauer, R.G. Hill, R.V. Law, J. Mater. Chem. 22, 15 (2012) 7395.

[36] E.A.Aguilar-Reyes, C.A. León-Patiño, B. Jacinto-Diaz, L.-P. Lefebvre, J. Am. Ceram. Soc. 95, 12 (2012) 3776.

[37] Y. Wang, X. Li, J. Chang, C. Wu, Y. Deng, J. Dent. 40, 12 (2012) 1119.

[38] J. Faure, R. Drevet, A. Lemelle, N.B. Jaber, A. Tara, H.E. Btaouri, H. Benhayoune, Mater. Sci. Eng. C 47 (2015) 407.

[39] A. Nommeots-Nomm, J. Massera, in "Scaffolds in tissue engineering - materials, technologies and clinical applications", F. Baino (Ed.), IntechOpen (2017) 867.

[40] C. Yang, X. Wang, B. Ma, H. Zhu, Z. Huan, N. Ma, C. Wu, ACS Appl. Mater. Interfaces 9, 7 (2017) 5757.

[41] A.W. Huang, C. Santos, R.O. Magnago, R.F.F. Silva, K. Strecker, J.K.M.F. Daguano, Cerâmica 61, 358 (2015) 160.

[42] M.C. Crovace, M.T. Souza, C.R. Chinaglia, O. Peitl, E.D. Zanotto, J. Non. Cryst. Solids 432 (2016) 90.

[43] S. Thomas, P. Balakrishnan, M.S. Sreekala, S. Mukhopadhyay, in "Fundamental biomaterials: ceramics", Woodhead Publ. (2018) 129.

[44] T. Fu, J. Sun, Y. Zhao, L. Wang, Y.Zhou, X. Ma, Ceram. Int. 43, 16 (2017) 13689.

[45] S. Cañaveral, D. Morales, A.F. Vargas, Mater. Lett. 255 (2019) 126575.

[46] A. Moghanian, S. Firoozi, M. Tahriri, A. Sedghi, Mater. Sci. Eng. C 91 (2018) 349.

[47] Q.-Z. Chen, G.A. Thouas, Acta Biomater. 7, 10 (2011) 3616.

[48] J. Qian, Y. Kang, Z. Wei, W. Zhang, Mater. Sci. Eng. C 29, 4 (2009) 1361.

[49] L. Floroian, B. Savu, G. Stanciu, A. Popescu, F. Sima, I. Mihailescu, R. Mustata, L. Sima, S. Petrescu, D. Tanaskovic, D. Janackovic, Appl. Surf. Sci. 255, 5 (2008) 3056.

[50] M. Uddin, M. Rashid, J. Taweekun, K. Techato, R. Roy, M. Ahbab, Int. J. Renew. Energy Resour. 8 (2018) 7.

[51] H.A.T. Banu, P. Karthikeyan, S. Meenakshi, Bioresour. Technol. Rep. 8 (2019) 100331.

[52] F. Frajkorová, K. Bodisová, M. Bohác, E. Bartonícková, Ceram. Int. 41, 8 (2015) 9770.

[53] ISO10993-5:2009, "Biological evaluation of medical devices, part 5: tests for cytotoxicity: in vitro methods", Int. Stand. Org., Genève (2009).

[54] M.R. Shahrouzifar, E. Salahinejad, Ceram. Int. 45, 8 (2019) 10176.

[55] F.B.A.P. Guimarães, B.R. Barrioni, A.C.X. Olivera, A.A.R. Oliveira, M.M. Pereira, Cerâmica 62, 364 (2016) 328.

(Rec.05/04/2020, Rev. 25/05/2020, Ac. 29/05/2020) 